\title{
Building Governance and Energy Efficiency: Mapping the Interdisciplinary Challenge
}

\author{
Frankie McCarthy, Susan Bright, and Tina Fawcett
}

\begin{abstract}
Improving the energy efficiency of multi-owned properties (MoPs) - commonly known as apartment or condominium buildings - is central to the achievement of European energy targets. However, little work to date has focused on how to facilitate retrofit in this context. Drawing on interdisciplinary Social Sciences and Humanities expertise in academia, policy and practice, this chapter posits that decision-making processes within MoPs might provide a key to the retrofit challenge. Existing theories or models of decision-making, applied in the MoP context, might help to explain how collective retrofit decisions are taken-or overlooked. Insights from case studies and practitioners are also key.
\end{abstract}

F. McCarthy $(\bowtie)$

School of Law, University of Glasgow, Glasgow, UK

e-mail: frankie.mccarthy@glasgow.ac.uk

S. Bright

Centre for Socio-Legal Studies, University of Oxford, Oxford, UK

e-mail: susan.bright@law.ox.ac.uk

T. Fawcett

Environmental Change Institute, University of Oxford, Oxford, UK

e-mail: tina.fawcett@eci.ox.ac.uk

(C) The Author(s) 2018

C. Foulds, R. Robison (eds.), Advancing Energy Policy, https://doi.org/10.1007/978-3-319-99097-2_6 
Theories of change might then be employed to develop strategies to facilitate positive retrofit decisions. The chapter maps the issues and sets an agenda for further interdisciplinary research in this novel area.

Keywords Energy efficiency $\bullet$ Apartments $\bullet$ Condominiums • Collective action $\bullet$ Governance

\subsection{CONTEXT}

Around $40 \%$ of European citizens live in multi-owned (apartment or condominium) buildings (Bright and Weatherall 2017). Improvements to the energy efficiency of multi-owned properties (MoPs) and the energy behaviour of residents are therefore essential to the achievement of Europe's energy goals. Existing work on energy efficiency in the housing context tends to focus on single-family dwellings, ignoring the additional complexities which arise where the participation of multiple parties is required (Matschoss et al. 2013; Weatherall et al. 2017). The Governance and Renewable Energy in Efficient Apartments Network for the European Union (GREEAN-EU) is an interdisciplinary research network of researchers, policymakers and practitioners that was formed to address this gap in the academic and policy discussion. The focus of the network is on how the opportunities for energy efficiency and upgrades in MoPs are affected by building governance (as explained in Bright and Weatherall 2017). This requires an understanding of 'the technology of law', that is, how in different European jurisdictions MoP laws structure decisions about the use of energy and energy-related technologies ('energy decisions'). This will depend on country-specific legal rules, practices, title and ownership arrangements used to regulate management of MoPs, as well as the way in which law mediates and structures decision-making. Energy decisions are impacted not only by these legal considerations but also by organisational factors, that is, how human actors work as a decisionmaking community, yet little attention has previously been given to understanding this in the context of MoPs.

This chapter reports on discussions from a workshop in Oxford in March 2018. The workshop's objective was to develop a conversation around new research approaches for understanding MoP energy-related 
decision-making processes by bringing together both legal and organisational aspects of building governance. The workshop was exploratory, with participants who covered a broad range of disciplines within the Social Sciences and Humanities. As well as experts in property law and energy policy and practice, most of whom were already familiar with our research questions, it included researchers in Psychology, Sociology and Economics with expertise in group decision-making, but not necessarily in relation to the European energy agenda or MoPs. Participants were invited based on knowledge of their existing work and its relevance to our research agenda. Whilst discussions were inevitably partial and selective, representing the perspectives of the (sub)disciplines represented at the workshop, this chapter offers substantive insights on how disciplinary perspectives can be integrated to provide answers to this critical research question and practical insights on how to conduct this work effectively. In line with the aims of the GREEAN-EU network, this chapter sets out the need for solutions (to the challenges presented by this critical but overlooked area within the European energy field) to be developed by working across disciplinary boundaries inside and outside the academic world. By doing so, it will contribute to new ideas on how the governance barrier to energy efficiency can be reduced, removed or transformed into a positive driver.

\subsection{Building Governance and Energy EfFiciency: Key Research Questions}

Article 19 of the 2012 Energy Efficiency Directive (2012/27/EU) requires member states to take appropriate measures to remove regulatory and nonregulatory barriers to energy efficiency in MoPs. Property law is central to this obligation, and yet its role has gone largely unexamined (Bright and Weatherall 2017). Bright and Weatherall began addressing this key aspect of energy behaviour through their Futureproofing Flats project, which provided a basis for the development of the 'Building Governance Model' (Bright and Weatherall 2017), a new framework within which to conduct an investigation in a range of European jurisdictions of the challenges of $\mathrm{MoP}$ retrofit. Its starting point was the literature on the 'energy efficiency gap' between actual energy use and optimal levels of energy efficiency (Hirst and Brown 1990; Jaffe and Stavins 1994), which includes a range of barrier models explaining the existence of this gap in particular contexts (Lutzenhiser 1993; Sorrell et al. 2011; Janda et al. 2015). Within that 
literature, some recent work has focused on the barriers specific to MoPs (Matschoss et al. 2013; LEAF 2016). The LEAF project, for example, grouped the challenges for multi-family properties into four categories: technical issues, agreement issues, financial issues and the behaviour of residents. Drawing on this research, the Building Governance Model posits governance as a type of meta-category which both represents and shapes the barriers described in earlier models. The structure within which energy decisions can be taken in MoPs is delineated by a combination of the law of property and the law of associations. Property law rules as to who owns which parts of a MoP building (such as the roof, windows and foundations) play a role in determining who, if anyone, has the power to instruct retrofit work. The law of associations structures how decisions involving multiple owners or residents can be taken, including meeting arrangements, voting processes and decision-making thresholds. A combination of these rules will determine who holds responsibility for the costs of the work, and whether and how finance can be accessed. The complexity of the law, in conjunction with regulation determining the availability of data on the energy efficiency of the building and the range of improvements possible, can create significant informational challenges for decision-makers. Law, therefore, creates a unique set of challenges to MoP energy efficiency.

The Building Governance Model draws attention to two further areas for investigation that require interdisciplinary collaboration between academics across the Social Sciences and Humanities, as well as with legal and energy practitioners and experts from the policy community. The first research area concerns gathering the data necessary to understand the full scope of the governance challenge. To address this, a cross-European group of property law researchers and energy policy practitioners within GREEAN-EU are developing a set of interdisciplinary methodologies for collection and analysis of data on relevant legal frameworks, building stock, energy use and energy performance in MoPs. The second research area concerns the process of energy-related decision-making within MoPs. The central ambition here is to develop a framework within which to understand how complex groups may be able to take energy decisions that benefit them collectively as well as individually. This chapter draws on the expertise represented at the Oxford workshop in order to explore how different disciplinary insights can contribute to that framework. 


\subsection{Energy Decision-Making in MoPs: Issues FOR FurTher RESEARCH}

The workshop provided an opportunity for all participants to better understand GREEAN-EU's research questions and to consider how expertise from their respective fields could be brought together to address those questions. The day entailed (i) an overview of GREEAN-EU's work, (ii) a review of earlier related projects carried out by attendees, (iii) a 'teach-in' where attendees outlined the contribution their discipline might make to addressing the decision-making question and (iv) a 'hackathon' where combinations of attendees explored how they might collaborate to take this work forward.

The issues around MoP energy-related decision-making were mapped within two broad questions. First, how are energy-related decisions taken in MoPs? This focuses on describing existing processes and identifying the reasons for them. Second, how can this understanding of decision-making processes be used to accelerate the rate of energy renovations to MoP buildings? This focuses on understanding how changes to the legal, social and economic context within which decisions are made might lead to better energy outcomes. Drawing on the cross-disciplinary academic and practitioner expertise represented at the workshop, we identified a range of possible approaches to addressing these questions and outlined the further research that would be required to develop a complete interdisciplinary methodology here.

The workshop also revealed potential gaps in our disciplinary coverage. On the academic side, we concluded that collaboration with researchers in Anthropology and Human Geography might offer useful insights into decision-making. On the practitioner side, expertise from the fields of investment/financing, communication and group mediation would be beneficial in developing strategies for changing the outcomes of decisionmaking processes.

\subsubsection{How Ave Energy-Related Decisions Taken in MoPs?}

\subsubsection{Understanding Collective Decision-Making}

Various models of decision-making within the Social Sciences were discussed which may be useful in understanding decision-making in apartment blocks. This was not a comprehensive discussion of all models of 
human choices, actions or practices, and theories which decentre the individual, such as Social Practice Theory, are not represented here. Some models, such as Collective Efficacy Theory developed by sociologist Robert Sampson in the context of controlling crime (Sampson et al. 1997), focus on the importance of wider groups in activating social ties to achieve collective goals and examine the contextual factors which support or obstruct that control. Others focus more upon the importance of wider groups in individual choices. The Theory of Planned Behaviour (Ajzen 1991), as used in Social Psychology, considers that decisions result from three sets of beliefs held by the decision-makers: about the likely consequences of decisions (attitudes), about the normative expectations of others inside and outside the group in respect of the decision (subjective norms) and about factors which may support or obstruct the performance of the decision (controls). Although this theory has been very influential in understanding decisions, some commentators suggest that it does not help practitioners to develop helpful interventions (Sniehotta et al. 2014). Social Identity Theory (Tajfel and Turner 1986) seeks to explain the actions of individuals by reference to the groups to which they consider themselves to belong. Thus, behaviours or decisions of the individual may be influenced by others who they see as fellow 'in-group members'. On the other hand, the Bystander Intervention Model (Darley and Latane 1968) predicts that under conditions of ambiguity of responsibility or where there is perceived diffusion of responsibility, individuals may fail to act (e.g. to improve energy efficiency).

A key research question is whether these theories can be usefully adapted to the MoP context. The ACE Retrofitting (2018) project, through which local governments aim to accelerate the energy retrofitting of condominiums by acting as facilitators between co-owners and building professionals, makes use of the Theory of Planned Behaviour in its work on development of tools for accelerating change. But there is a need for more Social Science research to understand how energy decision-making is best explained in the MoP context and what can be learned from this to support better energy outcomes.

\subsubsection{Forming the Collective}

The models described above aim to understand the behaviours of a group once it has formed. In MoPs, however, it is not necessarily the case that the individuals with power to take retrofit decisions perceive themselves as 
a group or act in a collective manner. In legal systems like Scotland and England, ownership of part of a MoP does not carry with it any obligation to meet with fellow owners or to establish a body (like an owners' association) to act in their collective interests; apartment owners may perceive themselves simply as individuals who happen to share a building (Weatherall et al. 2017). In legal systems such as France-where establishment of an owners' association and employment of a property manager are mandatory-although owners may understand themselves to be part of a collective, they may not consider themselves to have responsibility for the collective, viewing that instead as the role of the manager.

Addressing this aspect of MoP behaviour requires an understanding of how groups come to be formed. However, there appears to be no global theory within any of the disciplines represented in GREEAN-EU that can help us to understand this process. Further research is needed to fill this gap.

\subsubsection{Use Decisions and Investment Decisions}

Our workshop discussions suggested that decisions regarding energy can be broadly split into use and investment decisions. Use decisions, such as what temperature homes are heated to, are more usually conceptualised as habits, behaviours or practices. Investment decisions, including energy renovation and retrofit works, require a conscious decision to invest. It is these latter decisions which form the focus of GREEAN-EU's work.

There is limited theoretical material to draw on in understanding this form of decision-making outside the field of Economics, where familiar models such as cost/benefit analysis tend to dominate. An underlying presumption in most economic models is that decisions are taken by an economically rational individual who has access to full information, has consistent and stable preferences, and only seeks to maximise their own expected utility. Critics have long argued that this presumption has little basis in reality (Raworth 2017), which has led to the development of new 'behavioural' models of decision-making (e.g. Nudge Theory, explained below). Perhaps more problematically for our research, a model which focuses on the actions of individuals is unlikely to capture the necessary collective aspect of the investment behaviour with which we are concerned. Again, further research would be needed to fill this gap. 


\subsubsection{One Size Does Not Fit All}

A final concern relates to the heterogeneity of MoP collectives. The number of individuals involved may range from a minimum of two up to a maximum of several thousand people. As previously discussed, the ownership and management structures will vary from country to country based on domestic legal rules and practices. Cultural context is also likely to play a role in how a group functions. It is important to be aware of the risk of reductionism in attempting to explain the behaviour of every MoP collective by reference to a single model. Retaining an understanding of the differences between groups based on scale, organisation or other factors may be critical to the development of effective solutions.

\subsubsection{How Can Understanding MoP Energy Decision-Making Help Accelerate the Rate of Energy Retrofit?}

\subsubsection{Theories of Change}

In addition to awareness of how energy decisions are taken in the MoP setting, it is also important to consider how decision outcomes can be aligned with the ambitions of the European Energy Union. Explaining collective action, that is, how groups take action to achieve a common objective when there may be misalignments between individual and collective incentives, has been a challenge within several branches of the Social Sciences. Amongst various theories of change that may be apposite to the MoP energy context, both Nudge Theory and Social Marketing approaches were discussed at the workshop, whilst noting that the interaction between the role of the individual owner and the collective introduces complexity. Nudge Theory considers that suggestion or 'choice architecture' may be the most effective way of influencing decision-making behaviour. A policy tool of 'green nudges' is beginning to emerge which recognises specific issues in the environmental context, for example, the non-economic nature of perceived benefits from energy efficient behaviour, and the challenges of persuading individuals who are sceptical about the existence of climate change of any benefits to this behaviour. A Social Marketing approach concentrates on identifying the barriers to energy efficient behaviour or decisions, such as bystander effect factors and mental models/folk theories (incorrect but tenacious assumptions about the type of behaviour which 
is efficient), and employing techniques to overcome them. However, these theories or change mechanisms have been developed primarily in the context of habitual behaviour change, rather than investment decisions.

Having a 'champion' within the group to spearhead collective action can be powerful. Such leaders may be viewed as 'spokespersons' of energy transition from the perspective of the Actor Network Theory (Akrich et al. 2006 ) or as innovative 'in-group' members from the perspective of Social Identity Theory. Case study evidence suggests a champion can play a critical role in relation to MoPs where energy renovations have been undertaken (Brisepierre 2011; Le Garrec 2014). Empirical sociological research in France has found that energy improvement decisions in MoPs are often initiated by leaders or groups of leaders living within the building who persuade the wider community to take action. This confirms previous observations made by sociologists who studied French condominiums with the strategic analysis tools provided by the Sociology of Organised Action (Crozier and Friedberg 1977; Golovtchenko 1998; Lefeuvre 1999). From these studies, it is clear that collective action in a condominium depends on the skills of the actors and the capacity for building consensus.

In taking this aspect of our research agenda forwards, a first step would be to identify more case study examples of MoPs in which retrofits have been carried out in order to identify the mechanisms at play in the decisionmaking process. This research would need to be open to a wide range of theoretical frameworks, not necessarily just those discussed in our workshop.

\subsubsection{Levers for Change}

GREEAN-EU's focus on governance has the result that changes to the law may tend to be foregrounded in our development of proposals for change. However, it is important to avoid becoming blinkered in this respect. A number of practical and policy levers could be utilised, as identified through practitioner and case study experience, as well as from theoretical insights. In particular, the role of actors outside the MoP collective, such as property managers and building professionals (architects, contractors, etc.), could be critical. French sociological research has also highlighted the importance of neutral advice provided by local energy agencies, 
energy information desks or consumer associations supporting MoP representatives. The role of cities and the potential for them to drive action in relation to retrofit should also be kept in mind. The availability and regulation of finance for retrofit work are also important. Most fundamentally, the availability and accessibility of information about the types of energy renovation possible in different MoP buildings and the legal and financial measures necessary to undertake the work must meet the needs of MoP collectives, or it is unlikely that any progress can be made.

\subsection{Energy Decision-Making in MoPs: Practical Challenges of Further Research}

In addition to the considerable difficulties with integrating different research approaches within the Social Sciences and Humanities (one example being multiple understandings of the 'active consumer'-Fox et al. (2017)), there are also practical challenges with conducting panEuropean interdisciplinary research. These may sound marginal, but discussion in our workshop suggested they present real barriers to collaborative work. A summary of the principal challenges we identified, broken down into key aspects along with suggested solutions, is set out in Table 6.1. Awareness of these issues at an early stage is likely to prove essential to further research in this area.

Table 6.1 Challenges of interdisciplinary research

\begin{tabular}{|c|c|c|}
\hline Challenge & Key aspects & Suggested solutions \\
\hline $\begin{array}{l}\text { Levels of } \\
\text { interdisciplinary } \\
\text { expertise }\end{array}$ & $\begin{array}{l}\text { - Interdisciplinary work more common } \\
\text { in some disciplines than others } \\
\text { - Historically rare within law, the } \\
\text { central focus of our work } \\
\text { - Work with non-academics in policy } \\
\text { and practice present different } \\
\text { challenges }\end{array}$ & $\begin{array}{l}\text { - Share biographies } \\
\text { amongst project team } \\
\text { to foster awareness of } \\
\text { experience levels } \\
\text { - } \quad \text { Discuss issue at first } \\
\text { team meeting and } \\
\text { suggest reading as } \\
\text { necessary } \\
\text { - Encourage questions }\end{array}$ \\
\hline
\end{tabular}


Table 6.1 continued

\begin{tabular}{|c|c|c|}
\hline Challenge & Key aspects & Suggested solutions \\
\hline $\begin{array}{l}\text { Variation in } \\
\text { disciplinary styles } \\
\text { and methods }\end{array}$ & $\begin{array}{l}\text { Methodological expertise unlikely to } \\
\text { be shared by all, and 'shared' } \\
\text { methodologies (e.g. theoretical } \\
\text { analysis, historical analysis) may have } \\
\text { different meanings in different } \\
\text { disciplines } \\
\text { - Variation in conventions of writing } \\
\text { (active/passive voice, article length, } \\
\text { approaches to referencing) between } \\
\text { disciplines and between academics } \\
\text { and non-academics } \\
\text { Identification of appropriate } \\
\text { journals/outlets for publication }\end{array}$ & $\begin{array}{l}\text { - Ensure awareness of } \\
\text { issue } \\
\text { - Basic explanations of } \\
\text { key methodologies by } \\
\text { team members at } \\
\text { early meeting } \\
\text { - Develop 'style guide' } \\
\text { for writing } \\
\text { - Create regular } \\
\text { opportunities for } \\
\text { discussion of issues as } \\
\text { they arise }\end{array}$ \\
\hline Language barrier & $\begin{array}{l}\text { - Language used for project will not } \\
\text { be first language of all team members } \\
\text { - Technical terms may have different } \\
\text { meanings in different disciplines } \\
\text { - Legal terms may vary by jurisdiction }\end{array}$ & $\begin{array}{l}\text { - Ensure awareness of } \\
\text { issue } \\
\text { - Develop 'glossary' of } \\
\text { key project terms }\end{array}$ \\
\hline Communication & $\begin{array}{l}\text { - Varying expectations of working } \\
\text { - } \text { Ideurs by discipline and country } \\
\text { for virtual team meetings } \\
\text { - Funding for in-person meetings } \\
\text { - Most effective structure for meetings }\end{array}$ & $\begin{array}{l}\text { Discuss issue at first } \\
\text { team meeting and } \\
\text { develop protocol } \\
\text { covering these issues }\end{array}$ \\
\hline Management & $\begin{array}{l}\text { Manager(s) must maintain overview } \\
\text { of whole project } \\
\text { Keep up with developments across } \\
\text { disciplines and in European energy } \\
\text { policy }\end{array}$ & $\begin{array}{l}\text { - Ensure time is } \\
\text { factored in for } \\
\text { management } \\
\text { Build in structures for } \\
\text { regular } \\
\text { communication to } \\
\text { and from manager(s) } \\
\text { re: developments }\end{array}$ \\
\hline
\end{tabular}

\subsection{NEXT STEPS}

By building a broader multi-disciplinary network, and mapping key research questions, this work has laid the foundations for the next stage of the GREEAN-EU project. Several theories of change have been identified as potentially relevant to the decision-making question, both in terms of understanding current behaviour and in developing tools for changing that behaviour. 
Subject to securing funding, GREEAN-EU aims to develop the research down two connected pathways. One is a comprehensive desk-based exploration of the applicability of the identified theories in the MoP decisionmaking context. The other is identification of a number of case study MoPs in order to carry out empirical investigation of their experience of retrofit decision-making, testing the application of these theories of change in practice. This work should provide the data necessary for development of a methodology for a more comprehensive study, to include development of tools for change. In the meantime, it is hoped that this initial agenda-setting exercise will encourage further discussion and increased awareness of this critical issue in the European energy transition.

Acknowledgements The contributions of all the workshop attendees were invaluable in writing this piece. In addition to the authors, the attendees were Dr Christopher Decker, University of Oxford (Law and Economics); Dr Sylvaine Le Garrec, Consultant, Paris (Sociology); Dr Julie Goodhew, University of Oxford (Environmental Psychology); Professor Magdalena Habdas, University of Silesia (Law); Professor Miles Hewstone, University of Oxford (Social Psychology); Dr Sandra Passinhas, University of Coimbra (Law); Professor Vincent Sagaert, KU Leuven (Law); Professor Sergio Nasarre-Aznar, University Rovira i Virgili (Law); David Weatherall, Future Climate, London (Energy Policy); Dr Annemarie van Zeijl-Rozema, Maastricht University (representing the ACE Retrofitting project) (Sustainability Science/Co-creation).

Information on GREEAN-EU is available at http://futureclimate.org.uk/ greean/. We are also grateful to SHAPE ENERGY and the University of Oxford Law Faculty Research Support Fund for funding the Oxford workshop.

\section{REFERENCES}

ACE Retrofitting. (2018). Accelerating Condominium Energy Retrofitting. [online]. Retrieved March, 2018, from http://www.nweurope.eu/projects/ project-search/accelerating-condominium-energy-retrofitting-ace-retrofitting/

Ajzen, I. (1991). The Theory of Planned Behavior. Organizational Behavior and Human Decision Processes, 50(2), 179-211.

Akrich, M., Callon, M., \& Latour, B. (Eds.). (2006). Sociologie de la traduction: textes fondateurs. Paris: Mines ParisTech, les Presses Sciences Sociales.

Bright, S., \& Weatherall, D. (2017). Framing and Mapping the Governance Barriers to Energy Upgrades in Flats. Journal of Environmental Law, 29(2), 203-229. 
Brisepierre G. (2011). Les conditions sociales et organisationnelles du changement des pratiques de consommation d'énergie dans l'babitat collectif, Thèse de sociologie sous la direction de Dominique Desjeux, soutenue le 19 septembre 2011 à L'université Paris Descartes.

Crozier, M., \& Friedberg, E. (1977). L'Acteur et le système. Paris: Editions du Seuil.

Darley, J. M., \& Latane, B. (1968). Bystander Intervention in Emergencies: Diffusion of Responsibility. Journal of Personality and Social Psychology, 8(4, Pt.1), 377-383.

Fox, E., Foulds, C., \& Robison, R. (2017). Energy \& the Active Consumer-A Social Sciences and Humanities Cross-cutting Theme Report. Cambridge: SHAPE ENERGY.

Golovtchenko, N. (1998). Les copropriétés résidentielles entre règle juridique et régulation sociale. Contribution à une sociologie de l'action organisée, Thèse de doctorat sous la direction d'A. Bourdin, université de Toulouse-II, pp. 464.

Hirst, E., \& Brown, M. (1990). Closing the Efficiency Gap: Barriers to the Efficient Use of Energy. Resources, Conservation and Recycling, 3(4), 267-281.

Jaffe, A. B., \& Stavins, R. N. (1994). The Energy-efficiency Gap: What Does It Mean? Energy Policy, 22(10), 804-810.

Janda, K. B., Wilson, C., Bartiaux, F., \& Moezzi, M. (2015). Improving Efficiency in Buildings: Conventional and Alternative Approaches. In P. Ekins, M. Bradshaw, \& J. Watson (Eds.), Global Energy: Issues, Potentials and Policy Implications. Oxford: Oxford University Press Ch. 9.

Le Garrec, S. (Eds.). (2014). Qui sont les leaders énergétiques dans les copropriétés et quelles sont leurs stratégies, méthodes et bonnes pratiques pour favoriser la rénovation énergétique, Rapport final, Planète Copropriété, Plan Urbanisme Construction Architecture, [online]. Retrieved March 2018, from, http:// www.prebat.net/?Qui-sont-les-leaders-energetiques

Lefeuvre, M. P. (1999). La copropriété en difficulté. Faillite d'une structure de confiance. La Tour d'Aigues: Les Editions de l'Aube.

Low Energy Apartment Futures. (2016). Improving the Energy Efficiency of Apartment Blocks, LEAF Final Report. [online]. Retrieved March, 2018, from www.lowenergyapartments.eu

Lutzenhiser, L. (1993). Social and Behavioural Aspects of Energy Use. Annual Review of Energy and the Environment, 18, 247-289.

Matschoss, K., Heiskanen, E., Kranzl, L., \& Atanasiu, B. (2013). Energy Renovations of EU Multifamily Buildings: Do Current Policies Target the Real Problems? In: Proceedings of the ECEEE 2013 Summer Study. Stockholm: Berg.

Raworth, K. (2017). Doughnut Economics: Seven Ways to Think Like a 21st Century Economist. London: Random House. 
Sampson, R. J., Raudenbush, S. W., \& Earls, F. (1997). Neighborhoods and Violent Crime: A Multilevel Study of Collective Efficacy. Science, 277(5328), 918-924.

Sniehotta, F. F., Presseau, J., \& Araújo-Soares, V. (2014). Time to Retire the Theory of Planned Behaviour. Health Psychology Review, 8(1), 1-7.

Sorrell, S., Mallett, A., \& Nye, S. (2011). Barriers to Industrial Energy Efficiency: A Literature Review. Vienna: United Nations Industrial Development Organization.

Tajfel, H., \& Turner, J. C. (1986). The Social Identity Theory of Intergroup Behaviour. In S. Worchel \& W. G. Austin (Eds.), Psychology of Intergroup Relations (pp. 7-24). Chicago, IL: Nelson-Hall.

Weatherall, D., McCarthy, F., \& Bright, S. (2017). Property Law as a Barrier to Energy Upgrades in Multi-owned Properties: Insights from a Study of England and Scotland. Energy Efficiency. https://doi.org/10.1007/s12053-017-9540-5.

Open Access This chapter is licensed under the terms of the Creative Commons Attribution 4.0 International License (http://creativecommons.org/licenses/ by $/ 4.0 /$ ), which permits use, sharing, adaptation, distribution and reproduction in any medium or format, as long as you give appropriate credit to the original author(s) and the source, provide a link to the Creative Commons license and indicate if changes were made.

The images or other third party material in this chapter are included in the chapter's Creative Commons license, unless indicated otherwise in a credit line to the material. If material is not included in the chapter's Creative Commons license and your intended use is not permitted by statutory regulation or exceeds the permitted use, you will need to obtain permission directly from the copyright holder.

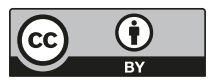

